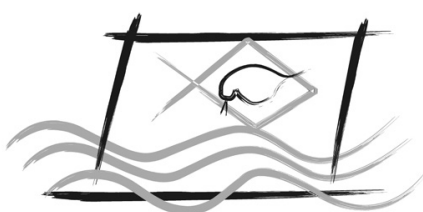

ECOTOX - BRASIL

\title{
The use of epibenthic copepod Tisbe biminiensis nauplii to assess the toxicity of seawater samples in Suape Bay (state of Pernambuco; Brazil)
}

\author{
L.P. De Souza-Santos ${ }^{1}$; D.D. De Oliveira ${ }^{1}$; E.S. Lima ${ }^{2}$ \\ ${ }^{1}$ Laboratório de Cultivo e Ecotoxicologia, Departamento de Oceanografia, Universidade Federal de Pernambuco - UFPE, Av.Arquitetura, \\ s/n, Recife, PE, Brazil. CEP 50670-901 \\ ${ }^{2}$ Departamento de Geologia da Universidade Federal de Pernambuco
}

(Received October 21, 2014; Accept August 27, 2015)

\begin{abstract}
Bioassays to determine the toxicity of water have been used worldwide as a tool of environmental monitoring. In the present study, the epibenthic copepod Tisbe biminiensis nauplius is proposed as a test organism for samples of seawater. Survival and the percentage of development from nauplius to copepodite were compared to the embryo-larval development of the sea urchin L. variegatus exposed to the same samples from the Suape estuarine system (state of Pernambuco, Brazil) collected in 2009. T. biminiensis naupliar development displayed a similar sensitivity to that found with the sea urchin embryos, mainly when simple t-test (not bioequivalent corrected) was used for sea urchin data. However, a lower sensitivity of copepod survival was found. The aluminium, iron and lead concentrations in surface waters were sometimes higher than Brazilian guidelines for estuarine water, probably due to dredging activities and anthropogenic contamination. These metals could be at least partially responsible for the toxic effects found at different stations and months. The results indicated that naupliar development of this epibenthic copepod is appropriate for the assessment of toxicity levels in seawater samples.
\end{abstract}

Keywords: Lytechinus variegatus, heavy metal, ecotoxicology, bioequivalence

\section{INTRODUCTION}

Toxicity tests conducted with the eggs and embryos of echinoderms are internationally accepted as adequate for the determination the toxicity levels in seawater (Environment Canada, 1992; USEPA, 1995; ASTM, 2004; ABNT, 2006). Such tests are widely employed in environmental assessments to characterize samples from effluents, water, sediment elutriate, interstitial water and the sediment-water interface (Cesar et al., 2004). According to Kobayashi (1974), tests with sea urchins are adequate for the measurement of toxicity levels and are easy to perform within a short time period. Moreover, such tests are sensitive, standardized and reliable.

In Brazil, Lytechinus variegatus is the sea urchin most often employed for ecotoxicology and embryo-larval toxicity tests with this species have been standardized by the Brazilian Association of Standards and Techniques (ABNT, 2006). However, a drastic decline in the population of $L$. variegatus has occurred in recent years, mainly along the northeastern coast of Brazil (Ihara et al., 2010). It has recently been included as vulnerable on the list of endangered fish and aquatic invertebrates of the Brazilian Ministry of the Environment (MMA, 2014), what restricts its capture and use. Thus, alternative toxicity tests that are as sensitive and efficient as the sea urchin embryo-larval test are needed.

Marine benthic copepods have been successfully used in toxicity tests since the late 1970s (Williams, 1992; Chandler \& Green, 2001; Chandler et al., 2004; Kusk \& Wollenberger, 2007; Fleeger \& Carman, 2011). Species from the genus Tisbe (Copepod: Harpacticoida) are suitable for ecotoxicological 
studies due to their wide geographic distribution, high ecological importance and short life cycle. Copepods at all developmental stages can be obtained at any time of the year from low-cost maintenance cultures with minimum space and equipment requirements (Williams, 1992; Kusk \& Wollenberger, 2007).

Standard 14669 of the International Standardization Organization (ISO, 1999) includes a protocol for determining acute seawater toxicity using three different marine copepods (including Tisbe battagliai) in different life cycle stages. The ASTM E-2317-04 protocol was also developed for ecotoxicity tests on the complete life cycle of the copepod Amphiascus tenuiremis in 96-well microplates (ASTM, 2004). The female harpacticoid copepod Tisbe biminiensis Volkman-Rocco (1973) has been successfully used in toxicity tests with sediments since 2003 (Araújo-Castro, 2008; Araújo-Castro et al., 2009). Recently, Lavorante et al. (2013) proposed a novel, simple ecotoxicological protocol for seawater samples using T. biminiensis nauplii. The authors demonstrated that the early development stages of this species are as sensitive as other copepod species, but less sensitive than $L$. variegatus embryos to zinc. However, no data was provided on the response of this organism to environmental samples. Moreover, Costa et al. (2014) suggested that benthic copepods are generally less sensitive to TBT than planktonic copepods, which may represent a restriction to the use of benthic copepod nauplii in seawater tests. However, planktonic copepods are more difficult to rear at high densities in the laboratory than Tisbe spp. (Drillet et al., 2011).

Due to the importance of the development of more adequately and sensitive tests in marine ecotoxicology, the aim of the present study was to assess the sensitivity of $T$. biminiensis nauplii exposed to environmental seawater samples by comparing these results with those obtained using L. variegatus embryos. The Suape estuarine area was selected for this study, since previous studies have detected sublethal toxicity in seawater samples using both $L$. variegatus embryos (Souza-Santos \& Araújo, 2013) and the microalgae Thalassiosira fluviatilis (Araújo \& Souza-Santos, 2013).

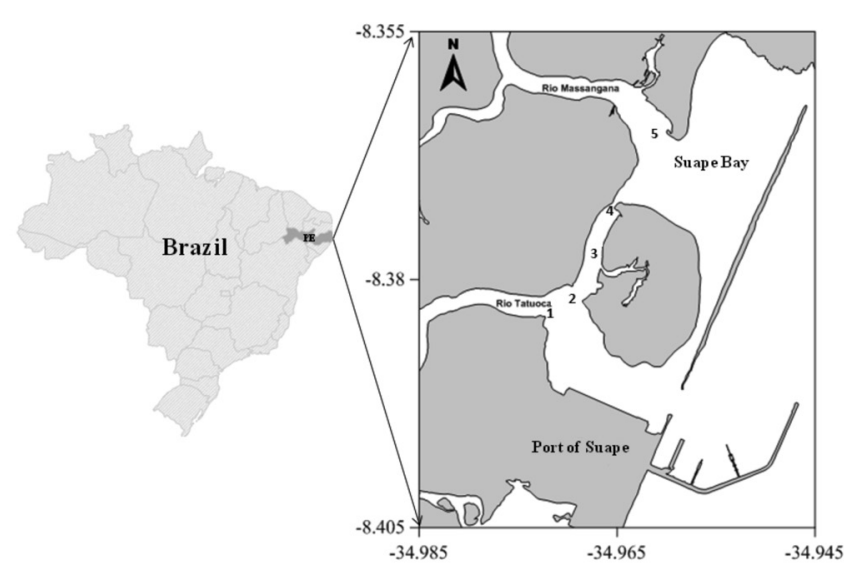

Figure 1: Suape estuarine system (state of Pernambuco, Brazil) and location of five stations where surface seawater was sampled.

\section{MATERIALS AND METHODS}

\section{Sample collection}

The Suape estuarine system is located on the southern coast of the state of Pernambuco in northeastern Brazil (Fig. 1). Construction of the Suape industrial port complex began in 1980 and the complex is currently the home to over one hundred companies performing diverse activities. This industrial development has led to environmental degradation, such as mangrove deforestation (Braga et al., 1989), a reduction in the both the diversity and abundance of fauna and flora (Koening et al., 2003; Silva et al., 2004, Bezerra Junior et al., 2011), drastic hydrodynamic changes (Paiva \& Araújo, 2010) and considerable potential for metal and hydrocarbon contaminations of water and sediment (Araújo-Castro, 2008, Marques et al., 2011; Souza-Santos \& Araújo, 2013; Araújo \& Souza-Santos, 2013; Lemos et al., 2014). The Suape complex is one of the largest ports in Brazil.

Surface water samples were collected from the Suape estuarine system in April, October, December 2009 and February 2010 at five stations: S1 (S 8 $\left.22^{\prime} 55^{\prime \prime}-\mathrm{W} 46^{\circ} 58^{\prime} 38^{\prime \prime}\right)$, $\mathrm{S} 2$ (S $8^{\circ} 22^{\prime} 50^{\prime \prime}$ - W $\left.46^{\circ} 57^{\prime} 59^{\prime \prime}\right), \mathrm{S} 3$ (S $8^{\circ} 22^{\prime} 30^{\prime \prime}-\mathrm{W} 46^{\circ} 57^{\prime}$ $\left.59^{\prime \prime}\right)$, S4 (S $\left.8^{\circ} 22^{\prime} 22^{\prime \prime}-\mathrm{W} 46^{\circ} 57^{\prime} 51^{\prime \prime}\right)$ and S5 (S $8^{\circ} 22^{\prime} 36^{\prime \prime}-$ $\mathrm{W} 46^{\circ} 57^{\prime} 45^{\prime \prime}$ ) (Fig. 1). Five sub-samples were collected in 100 $\mathrm{mL}$ polyethylene bottles during low spring tides at each station and stored in a thermal container with ice during transportation to the laboratory (ABNT, 2006). In the laboratory, the water samples were frozen at $-20^{\circ} \mathrm{C}$ and stored for a maximum of 60 days before the tests. One of the five sub-samples was used in the sea urchin test, another was used in the copepod test and the other three were stored for security.

Before the tests, measurements of salinity, $\mathrm{pH}$ and dissolved oxygen were taken. The salinity preference of both test organisms is similar (between 30 and 36) (ABNT, 2006; Souza-Santos et al., 2006). Thus, all samples with salinities between 20 and 30 were adjusted with brine, prepared after freezing filtered seawater, at a maximum proportion of $10 \%$ of the original sample.

\section{Toxicity tests with Lytechinus variegatus}

Sea urchins (L. variegatus) were collected during free dives at Itaipu beach (Niterói, state of Rio de Janeiro). The specimens were kept in thermal containers for transportation to the laboratory, where they were used on the same day.

The short-term sublethal toxicity tests with $L$. variegatus were carried out based on the ABNT (2006) protocol. Sea urchin embryos were exposed to test water samples for 24 to 28 hours. The endpoint of the test was the percentage of 2-arms pluteus larvae exhibiting normal (well formed) and anomalous (badly formed or delayed) development in comparison to control specimens. The control was a sample of $0.45 \mu \mathrm{m}$ of filtered seawater collected at Barra da Tijuca beach (state of Rio de Janeiro), where seawater usually presents good quality for swimming (Station 5). 
Test seawater samples were thawed in an environment protected from heat and direct sunlight and were considered ready for analysis upon reaching a temperature of $25 \pm 1{ }^{\circ} \mathrm{C}$. Five $10-\mathrm{mL}$ replicates were taken from a sub-sample from each station and placed in 40-mL glass test tubes with 300 fertilized $L$. variegatus eggs. The test tubes were maintained in an incubator at $25^{\circ} \mathrm{C}$ with a 12 -h light/dark cycle. The bioassay was ended after 24 to $28 \mathrm{~h}$, when at least $80 \%$ of the control organisms had reached the 2 arms pluteus stage, which was verified by identifying the developmental stages of the first 100 organisms from one of the control replicates. The tube contents were then fixed using $2 \%$ formalin buffered with borax.

The development stage and incidences of abnormalities among the first 100 organisms of each replicate were determined using a Sedgwick-Rafter chamber. Pre-pluteus larvae, poorly developed plutei in comparison to the control and deformed or badly formed organisms were considered abnormal. The bioassay was considered valid when at least $80 \%$ of the plutei in the control were well-formed. Pluteus development was the endpoint in this experiment.

\section{Toxicity tests with Tisbe biminiensis}

The toxicity tests conducted with $T$. biminiensis nauplii followed the methodology proposed by the ASTM (2004) with methodological changes based on the life cycle of species. One day before the start of the test, $T$. biminiensis adults maintained in laboratory cultures (Ribeiro \& Souza-Santos, 2011) were placed in a structure designed to separate newly hatched nauplii. One box was placed over a second box of the same size. The bottom of the upper box was replaced with a $120-\mu \mathrm{m}$ mesh, which was sufficiently large to allow the passage of the newly hatched nauplii. The lower box received $30 \mathrm{~mL}$ of concentrated microalgae (diatom) and four liters of seawater. The system remained stagnant until the microalgae were deposited on the bottom of the lower box to feed the nauplii without feeding the adults, thereby decreasing the production of fecal pellets. Adults $(>250 \mu \mathrm{m})$ were then added to the upper box and remained in the structure for approximately $20 \mathrm{~h}$. Newly hatched nauplii passed through the $120-\mu \mathrm{m}$ mesh and were stored in the lower box. The maximum age of the nauplii used in the test was $26 \mathrm{~h}$.

The test and control suspensions were prepared with the seawater samples at room temperature and the microalgae Thalassiosira fluviatilis (diatom) at a concentration of $0.1 \mu \mathrm{g}$ Chl-a $\mathrm{mL}^{-1}$. Three replicates were performed using three 96well plates for each test sample and control. Each replicate involved 30 nauplii. The control was natural seawater that had been previously filtered ( 25 and $5 \mu \mathrm{m})$ and stored. The nauplii were placed individually into one $300-\mu 1$ well using a Pasteur pipette, then only 30 wells were used per 96-well microplate. Empty wells were filled with distilled water to minimize evaporation and avoid variations in the established conditions. The microplates were covered and incubated under a controlled temperature of $28^{\circ} \mathrm{C}$ and a 12-h light/dark photoperiod.

As the naupliar stage lasts from 50 to $60 \mathrm{~h}$, depending on the feeding regimen at $29 \pm 1{ }^{\circ} \mathrm{C}$ (Pinto et al., 2001), the specimens were examined under a stereomicroscope every $12 \mathrm{~h}$ for a period of $48 \mathrm{~h}$. The percentage of survival (not-moving animals were considered dead) and percentage of copepodites among the live specimens were determined at the end of the test.

\section{Heavy metal concentrations in water}

Surface water samples for the determination of heavy metals were collected at the same time and place as the samples used for the toxicity tests in April, October and December 2009, using a 10-L polypropylene container. The samples were transferred to a 500-ml polyethylene bottles and preserved using concentrated $\mathrm{HNO}_{3}$. The samples were kept in a cooler with ice and taken to the laboratory, where they were acid digested using EPA 3005A method (EPA, 1992) for total recoverable metals and analyzed by ICP/AES using EPA method SW846-6010 (EPA, 2007).

\section{Statistical analyses}

All data were arcosin of the square root transformed and tested for normality using chi-square test and for homogeneity of variance using the F-test. Considering each sampling month individually, a seawater sample from each test station was compared to the control sample using both the t-test and bioequivalent $t$-test with the aid of the Toxstat 3.5 program. The b used in bioequivalent t-test for $L$. variegatus embryo was 0.91 (Bertoletti et al., 2007). The bioequivalent t-test was not used for the T. biminiensis test, as there were not enough historical data to estimate the $b$ value. Pearson's correlation coefficients were calculated to relate the most abundant heavy metal to the standardized (in relation to control) ecotoxicological endpoints. The significance level used for all tests was 5\%.

\section{RESULTS}

\section{Lytechinus variegatus}

In April 2009, using the t-test, all stations exhibited a significant decrease in the development of plutei (Fig. 2). However, using bioequivalent t-test, only stations 2, 3 and 4 were not bioequivalent to control (Fig. 2). In October 2009, using the t-test, seawater samples at stations 1,2 and 5 exhibited a significant decrease in the percentage of well-formed plutei (Fig.2). However, using bioequivalence, the stations were all bioequivalent to the control (Fig. 2). In December 2009, both statistical tests indicated that the percentage of well-formed plutei was significantly decreased at stations 1,4 and 5 (Fig. 2). In February 2010, the sea urchin test was not valid due to problems in the embryonic development among the controls.

\section{Tisbe biminiensis}

Regarding copepod survival, no sample demonstrated any significant difference from the control in April 2009 


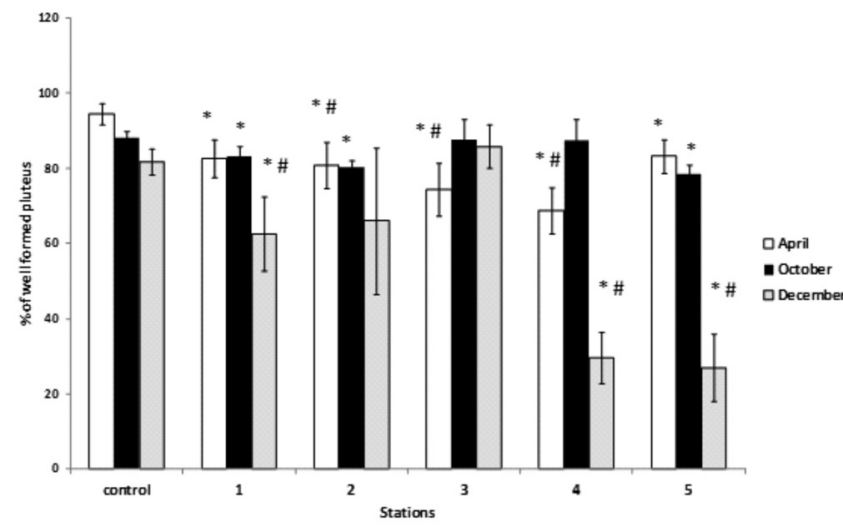

Figure 2: Mean $( \pm \mathrm{SD})$ percentage values of well-formed pluteus of Lytechinus variegatus in April, October and December 2009 when exposed to samples of surface water from Suape estuarine system (* indicate significant differences using $t$ test and \# indicate significant differences using bioequivalence $t$ test).

(Fig. 3). In relation to copepod development, significant delays in comparison to the control were found at stations 3, 4 and 5 (Fig.3)

In October 2009, copepod survival was significantly lower than the control at stations 4 and 5 (Fig. 4). Copepod development significantly decreased at all stations in comparison to the control and no copepodites developed at most stations (Fig. 4).

In December 2009, a significant decrease was found regarding survival at stations 2, 3 and 4 in comparison to the control (Fig. 5) and a significant decrease in copepod development occurred at stations 3,4 and 5 (Fig. 5).

In February 2010, the copepod development decreased significantly at only station 2 (Fig. 6).

\section{Comparison between test organisms}

The sea urchin test detected sublethal toxicity at 11 of the 15 sampling stations when the t-test was used for the statistical analyses. The bioequivalent approach detected only six toxic samples, decreasing the sensitivity of the sea urchin test in five samples (Tab. 1).

The sensitivity of the copepod test was compared to that of the sea urchin test considering both statistical analyses proposed for the sea urchin. The analysis of copepod survival detected lethal toxicity in only five samples, and three were not considered toxic using either of the sea urchin analysis (Tab. 1). The analysis of copepod development also detected sublethal toxicity in 11 of the 15 samples, only three of which were not considered toxic by the sea urchin test using the simple t-test. Considering the bioequivalent statistical analysis, however, the analysis of copepod development detected higher sublethal toxicity at seven stations. Only three and two toxic samples based on the simple t-test and bioequivalent $\mathrm{t}$-test, respectively, were not detected by the copepod endpoints.

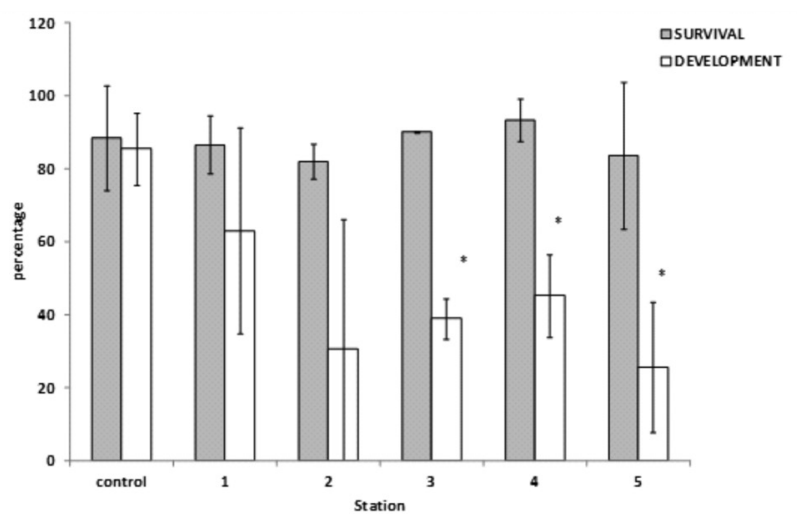

Figure 3: Mean ( $\pm \mathrm{SD}$ ) percentage values of development of copepodites and survival of juvenile Tisbe biminiesis copepods, at end of experiment with environmental samples from Suape estuarine system in April 2009, Pernambuco, Brazil (asterisks indicate significant differences using t-test.)

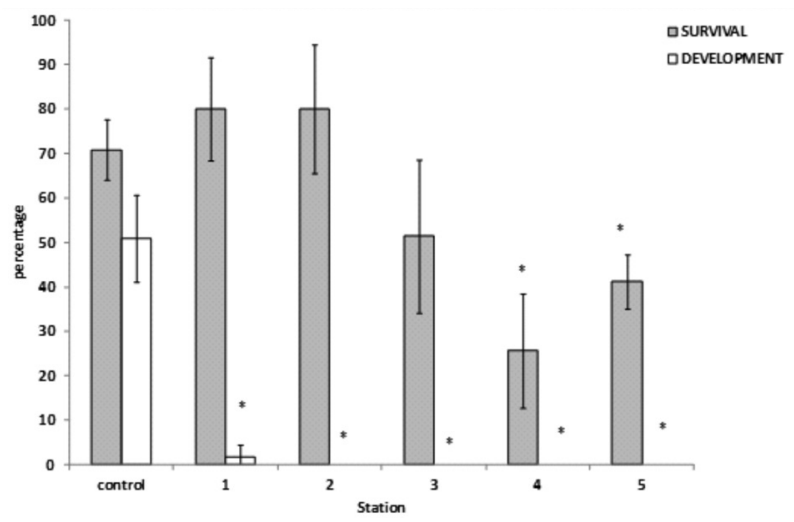

Figure 4: Mean ( \pm SD) percentage values of development of copepodites and survival of juvenile Tisbe biminiesis copepods, at end of experiment with environmental samples from Suape estuarine system in October 2009, Pernambuco, Brazil (asterisks indicate significant differences using t-test.)

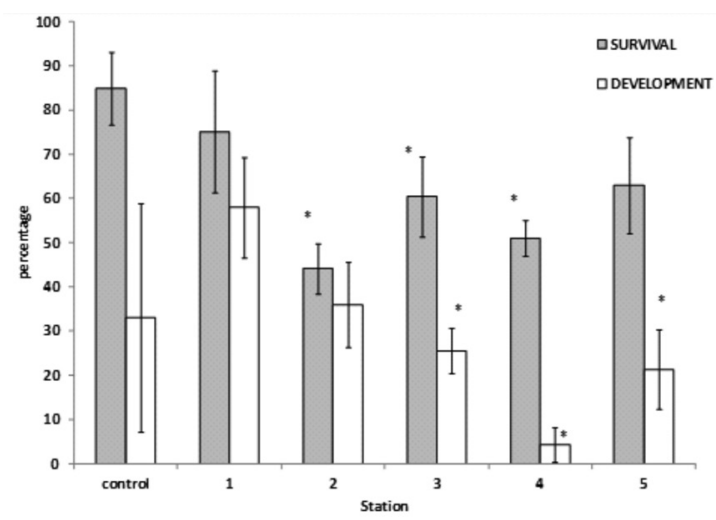

Figure 5: Mean $( \pm \mathrm{SD})$ percentage values of development of copepodites and survival of juvenile Tisbe biminiesis copepods, at end of experiment with environmental samples from Suape estuarine system in December 2009, Pernambuco, Brazil (asterisks indicate significant differences using t-test.) 


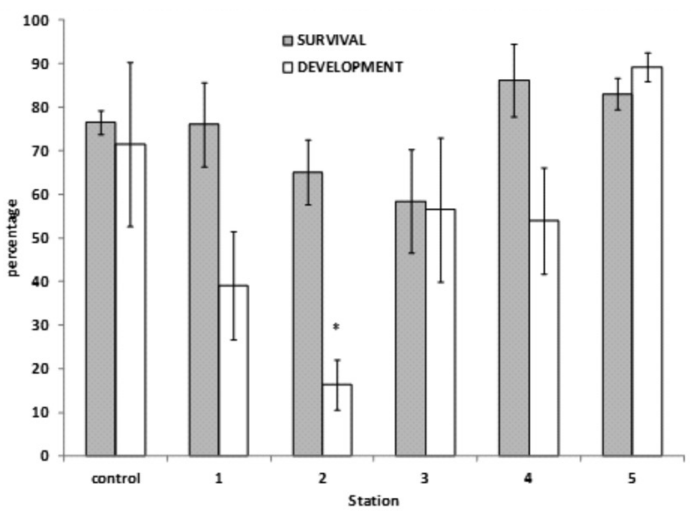

Figure 6: Mean $( \pm \mathrm{SD})$ percentage values of development of copepodites and survival of juvenile Tisbe biminiesis copepods, at end of experiment with environmental samples from Suape estuarine system in February 2010, Pernambuco, Brazil (asterisks indicate significant differences using t-test.)

Table 1- Comparison of toxicity endpoints in seawater samples from Suape Bay between April and December 2009: development of sea urchin Lytechinus variegatus embryos (using both simple t-test or bioequivalence t-test), 48-h mortality and naupliar development of Tisbe biminiesis. The similarity was the number of stations presenting the same results than the sea-urchin bioassay using t-test and bioequivalent t-test. More sensitivity indicated the number of stations where that endpoint/test-organism was more sensitive than the other test-organisms.

\begin{tabular}{|c|c|c|c|c|c|}
\hline \multirow[t]{2}{*}{ Month } & \multirow[t]{2}{*}{ Station } & \multicolumn{2}{|c|}{ Sea urchin results } & \multicolumn{2}{|c|}{ Copepod results } \\
\hline & & t-test & bioequivalence & Survival & development \\
\hline \multirow{5}{*}{ April 2009} & 1 & $\mathrm{~T}$ & $\mathrm{~B}$ & $\mathrm{~N}$ & $\mathrm{~N}$ \\
\hline & 2 & $\mathrm{~T}$ & $\mathrm{~T}$ & $\mathrm{~N}$ & $\mathrm{~N}$ \\
\hline & 3 & $\mathrm{~T}$ & $\mathrm{~T}$ & $\mathrm{~N}$ & $\mathrm{~T}$ \\
\hline & 4 & $\mathrm{~T}$ & $\mathrm{~T}$ & $\mathrm{~N}$ & $\mathrm{~T}$ \\
\hline & 5 & $\mathrm{~T}$ & $\mathrm{~B}$ & $\mathrm{~N}$ & $\mathrm{~T}$ \\
\hline \multirow{5}{*}{$\begin{array}{l}\text { October } \\
2009\end{array}$} & 1 & $\mathrm{~T}$ & $\mathrm{~B}$ & $\mathrm{~N}$ & $\mathrm{~T}$ \\
\hline & 2 & $\mathrm{~T}$ & $\mathrm{~B}$ & $\mathrm{~N}$ & $\mathrm{~T}$ \\
\hline & 3 & $\mathrm{~N}$ & $\mathrm{~B}$ & $\mathrm{~N}$ & $\mathrm{~T}$ \\
\hline & 4 & $\mathrm{~N}$ & $\mathrm{~B}$ & $\mathrm{~T}$ & $\mathrm{~T}$ \\
\hline & 5 & $\mathrm{~T}$ & $\mathrm{~B}$ & $\mathrm{~T}$ & $\mathrm{~T}$ \\
\hline \multirow{5}{*}{ December 2009} & 1 & $\mathrm{~T}$ & $\mathrm{~T}$ & $\mathrm{~N}$ & $\mathrm{~N}$ \\
\hline & 2 & $\mathrm{~N}$ & $\mathrm{~B}$ & $\mathrm{~T}$ & $\mathrm{~N}$ \\
\hline & 3 & $\mathrm{~N}$ & $\mathrm{~B}$ & $\mathrm{~T}$ & $\mathrm{~T}$ \\
\hline & 4 & $\mathrm{~T}$ & $\mathrm{~T}$ & $\mathrm{~T}$ & $\mathrm{~T}$ \\
\hline & 5 & $\mathrm{~T}$ & $\mathrm{~T}$ & $\mathrm{~N}$ & $\mathrm{~T}$ \\
\hline Similarity & & & 10 & 3 and 7 & 9 and 6 \\
\hline More sensitivity & & 3 & 2 & 3 and 4 & 3 and 7 \\
\hline $\begin{array}{l}\text { Percentage of } \\
\text { toxicity }\end{array}$ & & $11 / 15$ & $6 / 15$ & $5 / 15$ & $11 / 15$ \\
\hline
\end{tabular}

$\mathrm{T}$ is toxic, $\mathrm{B}$ is bioequivalent and $\mathrm{N}$ is non-toxic

\section{Heavy metal determination in water}

Table 2 shows that most of heavy metals analyzed in water samples were below the quantification limit of the method. However, aluminum, cadmium, iron, lead, manganese, titanium and vanadium were detected in seawater in some months and at some stations. $\mathrm{Al}, \mathrm{Fe}$ and $\mathrm{Pb}$ were the most abundant and more often detected metals in the samples. Table 3 displays Pearson's correlations coefficients between $\mathrm{Al}, \mathrm{Fe}$ and $\mathrm{Pb}$ concentrations and the ecotoxicological endpoints. To explain the observed toxic effect, only inverse correlations were considered, although no statistically significant correlation was found at 5\% probability. Al and Fe concentrations had a tendency to be inversely correlated to copepod development and $\mathrm{Pb}$ concentrations to copepod survival and pluteus development.

\section{DISCUSSION}

When surveying environmental toxicity, the use of three different species of different trophic levels is recommended to minimize the possibility of generating false negatives in monitoring programs, as each species has a specific sensitivity to different contaminants. For such, microalgae, invertebrates and fish are generally recommended for water samples. Another recommendation is the use of ecologically important organisms from the same type of habitat at that of the environmental samples tested, which means the use of benthic organisms to assess the sediment toxicity and pelagic organisms for water samples to make toxicological interpretations more reliable (Zagatto \& Bertoletti, 2006). For practical reasons, however, it is common however to use pelagic organisms to infer sediment toxicity and benthic organisms to assess water toxicity (ABNT, 2006; ISO, 1999). Benthic organisms are expected to be more resistant to some contaminants than pelagic organisms (for example see Costa et al., 2014) and may therefore produce false-negative responses, whereas pelagic organisms can lead to falsepositive responses in terms of sediment quality.

The sea urchin embryo-larval test offers considerable sensitivity in the monitoring of seawater samples. However, the decline of Lytechinus variegatus populations currently impedes this test in some regions of Brazil. Pelagic copepods are a viable alternative as test organisms for evaluating the toxicity of marine water samples, but difficulty in rearing planktonic species and the need for larger volumes of water and space in laboratories limit its utility for routine use. Thus, the use of Tisbe biminiensis may be a viable option. This epibenthic copepod species originally sampled from the city of Olinda (state of Pernambuco, Brazil) has been reared in the laboratory for many generations since 1998 and has a well-studied life cycle (Pinto et al., 2001; Souza-Santos et al., 2006; Ribeiro \& Souza-Santos, 2011). Adult females of this species were successfully used as test organisms to assess estuarine sediment quality (Araújo-Castro, 2008; Araújo-Castro et al., 2009). Lavorante et al. (2013) proposed a novel, simple protocol using $T$. biminiensis nauplii as test organisms for seawater samples, but did not test the method using environmental samples or compare their results to any another established protocol, as was done in the present study.

The similarity between the responses of the sublethal $L$. variegatus embryo-larval test, using simple t-test analyses, and the sublethal endpoint represented by the success of $T$. biminiensis naupliar development suggests that the latter organism could be useful in future seawater monitoring programs. The low sensitivity of the embryo-larval test using bioequivalent analyses compared to the copepod test indicates 
Table 2- Heavy metal concentration ( $\mu$ g. $\left.\mathrm{L}^{-1}\right)$ in water samples of Suape estuarine system in April, October (Oct) and December (Dec) 2009 and CONAMA 357/05 Resolution limits for estuarine class of water.

\begin{tabular}{|c|c|c|c|c|c|c|c|c|c|c|c|c|c|c|c|c|c|}
\hline \multicolumn{18}{|c|}{ Stations } \\
\hline & & & \multicolumn{3}{|c|}{1} & \multicolumn{3}{|c|}{2} & \multicolumn{3}{|c|}{3} & \multicolumn{3}{|c|}{4} & \multicolumn{3}{|c|}{5} \\
\hline & $\mathrm{CL}$ & QL & April & Oct & Dec & April & Oct & Dec & April & Oct & Dec & April & Oct & Dec & April & Oct & Dec \\
\hline $\mathrm{Al}$ & 100 & 100 & 849 & 1162 & 1986 & 861 & 14848 & 1358 & 1410 & 6759 & 909 & 4280 & 1380 & 991 & 3240 & 160 & 547 \\
\hline $\mathrm{Cd}$ & 5 & 5 & $<15$ & & & $<15$ & & & $<15$ & & & 21.3 & & & $<15$ & & \\
\hline $\mathrm{Cr}$ & 50 & 10 & $<30$ & & & $<30$ & & & $<30$ & & & $<30$ & & & $<30$ & & \\
\hline $\mathrm{Cu}$ & 5 & 10 & $<90$ & & & $<90$ & & & $<90$ & & & $<90$ & & & $<90$ & & \\
\hline $\mathrm{Fe}$ & 300 & 300 & $<900$ & 1943 & & $<\mathbf{9 0 0}$ & 4184 & & $<\mathbf{9 0 0}$ & 1668 & & 1270 & 357 & & 1770 & 351 & \\
\hline $\mathrm{Pb}$ & 10 & 10 & $<30$ & 32.5 & 178 & $<30$ & 36.4 & 187 & $<30$ & 48.6 & 164 & $<30$ & 41.9 & 134 & $<30$ & 37.8 & 143 \\
\hline $\mathrm{Mn}$ & 100 & 10 & $<30$ & 105 & & $<30$ & 21.5 & & $<30$ & & & $<30$ & & & $<30$ & & \\
\hline $\mathrm{Ni}$ & 25 & 10 & $<30$ & & & $<30$ & & & $<30$ & & & $<30$ & & & $<30$ & & \\
\hline $\mathrm{Ti}$ & & 10 & $<60$ & 11.2 & & $<60$ & 74.8 & & $<60$ & 32.3 & & $<60$ & & & $<60$ & & \\
\hline Sn & & 200 & $<60$ & & & $<60$ & & & $<60$ & & & $<60$ & & & $<60$ & & \\
\hline V & & 10 & $<30$ & 40.6 & & $<30$ & 38.3 & & $<30$ & 30.3 & & $<30$ & 21.6 & & $<30$ & 17.3 & \\
\hline $\mathrm{Zn}$ & 90 & 50 & $<150$ & & & $<150$ & & & $<150$ & & & $<150$ & & & $<150$ & & \\
\hline
\end{tabular}

$\mathrm{CL}$ is the CONAMA limit for brackish water class 1; QL is quantification limit; bold values are greater than CL

Table 3- Results of Pearson's correlation analyses (r) between ecotoxicological endpoints (expressed as percentage of controls) and $\mathrm{Al}$, $\mathrm{Fe}$ and $\mathrm{Pb}$ concentrations in seawater from Suape Bay between April and December 2009 (most important, although non-significant, negative correlations expressed in bold type)

\begin{tabular}{lccccc}
\hline & Pluteus development & Survival & $\begin{array}{c}\text { Copepod } \\
\text { development }\end{array}$ & Al & Fe \\
\hline $\begin{array}{l}\text { Survival } \\
\begin{array}{l}\text { Copepod } \\
\text { development }\end{array}\end{array}$ & 0.09 & 1 & - & & \\
Al & -0.17 & 0.02 & 1 & --- & --- \\
Fe & 0.22 & 0.39 & $\begin{array}{c}\mathbf{- 0 . 2 9} \\
(\mathbf{p}=\mathbf{0 . 3 0})\end{array}$ & 1 & --- \\
$\mathbf{P b}$ & 0.28 & 0.54 & $\begin{array}{c}\mathbf{- 0 . 4 3} \\
(\mathbf{p}=\mathbf{0 . 1 1})\end{array}$ & 0.90 & 1 \\
\hline & $\begin{array}{c}\mathbf{- 0 . 3 6} \\
(\mathbf{p}=\mathbf{0 . 1 9})\end{array}$ & $\begin{array}{c}\mathbf{- 0 . 4 7} \\
(\mathbf{p}=\mathbf{0 . 0 8})\end{array}$ & 0.62 & -0.22 & -0.3529 \\
\hline
\end{tabular}

that further studies are needed to validate this statistical analysis in the future. However, the protocol involving 96-well plates is not recommended, as the technical work proved very difficult. The use of groups of nauplii in seawater samples, as reported by Lavorante et al. (2013), seems to be a better protocol for this organism, as it is simpler.

Although T. biminiensis is classified as meiobenthic in size, it lives on the surfaces of sediment and macroalgae, making it epibenthic, which may explains why the sensitivity of this species in initial stages is similar to the planktonic larvae of a benthic sea urchin. Seawater toxicological tests with juvenile meiobenthic copepods have been proposed by the ISO (1999) with Tisbe battagliai copepodites in stage one (approximately two days old). Moreover, the ASTM (2004) has standardized toxicity tests using 24-h-old Amphiascus tenuiremis nauplii in 96-well microplates, which can detect changes in the whole life cycle caused by different pollutants, especially endocrine disruptors. The results of the present study suggest the use of Tisbe nauplii as a test organism for seawater samples

The present findings are corroborated when comparing $T$. biminiensis nauplius sensitivity to reference substances. Resgalla \& Laitano (2002) studied the sensitivity of $L$. variegatus embryos to potassium dichromate and reported an $\mathrm{EC}_{50}-24 \mathrm{~h}$ of $3.99 \mathrm{mg} \mathrm{Cr} \mathrm{L^{-1 }}$ and a no-observed-effect concentration (NOEC) of $1 \mathrm{mg} \mathrm{Cr} \mathrm{L}^{-1}$. T. biminiensis nauplii presented an $\mathrm{LC}_{50}-72 \mathrm{~h}$ of $1 \mathrm{mg} \mathrm{Cr} \mathrm{L}^{-1}$ and NOEC of $0.7 \mathrm{mg}$ $\mathrm{Cr} \mathrm{L}^{-1}$ (Araújo-Castro et al., 2006). Despite the different exposure times, $T$. biminiensis nauplii seem to be rather similar to potassium dichromate in terms of sensitivity than the first embryonic stages of $L$. variegatus. The sensitivity of T. biminiensis adults to potassium dichromate $\left(\mathrm{LC}_{50}-72 \mathrm{~h}\right.$ of $1.56 \mathrm{mg} \mathrm{Cr} \mathrm{L}^{-1}$ ) (Araújo-Castro et al., 2009) was lower than that determined for nauplii. With regard to zinc sulfate, $L$. variegatus embryos $\left(\mathrm{EC}_{50}-24 \mathrm{~h}\right.$ of $\left.0.048 \mathrm{mg} \mathrm{Zn} \mathrm{L}^{-1}\right)$ exhibited greater sensitivity than $T$. biminiensis nauplii $\left(\mathrm{EC}_{50}-72 \mathrm{~h}\right.$ of $0.75 \mathrm{mg} \mathrm{Zn} \mathrm{L}^{-1}$ ) (Lavorante et al., 2013). These data confirm that the relative sensitivity of an organism is dependent on the type of compound used and that $T$. biminiensis adults are less sensitive than their larval phases.

Larval development from nauplius to copepodite includes six phases of ecdysis and one metamorphosis, which characterizes the juvenile stage. The molting process and metamorphosis are regulated by hormones (Forget-Leray et al., 2005; Dahl et al., 2006). Lee et al. (2008) suggested that tests with nauplii are very useful, as the non-development of individuals can be directly related to the inhibition of hormones responsible for ecdysis and metamorphosis of the copepod. According to Bechman (1999), the metamorphosis, that takes place between the nauplius and copepodite stages, is the most important event in the life cycle of copepods. The tests performed in the present study revealed that the development from nauplius to copepodite was the most sensitive of the endpoints employed, probably due to the restriction of metamorphosis under stressful conditions.

Studying the $\mathrm{LC}_{50}$ in different stages of the life cycle of the copepod Tigriopus brevicornis, Forget et al. (1998) found that nauplii were two to four times more sensitive than the juvenile and adult stages. Huang et al. (2006) found that nauplii of the copepod Pseudodiaptomus marianus 
demonstrated greater sensitivity than copepodites when exposed to low concentrations of tributyltin oxide. The rate of larval development is an indication of how a pollutant acts in juvenile phases, possibly as an endocrine disruptor, and it likely appears at low, non-lethal concentrations (ForgetLeray et al., 2005). In a study on the life cycle of the copepod Amphiascus tenuiremis, Templeton et al. (2006) found lower numbers of copepodites and adults at the greatest concentration of the compound tested due to delayed development. Diz et al. (2009) found that T. battagliai nauplii were more sensitive to copper and linear alkylbenzene sulfonate than adults.

Surface waters of the Suape estuarine complex have been shown to exhibit sublethal toxicity in previous studies, using L. variegatus embryos to assess the quality of surface water in 2007, Souza-Santos \& Araújo (2013) found toxicity at all stations studied, which were nearly the same stations studied in the present investigation. In the same region, using both the diatom Thalassiosira weissflogii and L. variegatus embryos as test organisms, seawater toxicity was also found in 2010 and 2011 (Araújo \& Souza-Santos, 2013). The present findings with T. biminiensis nauplii and L. variegatus embryos in 2009 and 2010 also demonstrate surface seawater contamination in the Suape estuarine system.

The toxicity of surface seawater in this area depends on the sampling month. Souza-Santos \& Araújo (2013) reported greater toxicity to sea urchins in October 2007. Araújo \& Souza-Santos (2013) found that September 2010 and 2011 were the months with the greatest toxicity to the diatom $T$. weissflogii in the same region. In the present study, April and October 2009 were the months with the greatest toxicity to $T$. biminiensis nauplii and the water sampled in April 2009 had the greatest toxicity to the sea urchin. These worse conditions in spring seem to be associated with the end of the rainy season (March to August), when land contaminants could be accumulated in the estuarine water and become concentrated at the beginning of the dry season (September to February). Dredging activities in the area could be also associated with this temporal variation in water toxicity.

The origin of the toxicological effects of the water and sediments in the Suape system is not still fully understood. Total petroleum hydrocarbons in the waters of the Suape region was close to the baseline contamination level, but some high concentrations were likely associated with shipyard operations, the re-suspension of pollutants by dredging operations, occasional industrial discharges and oil derivatives from vessels (Lemos et al., 2014). Although most heavy metal concentrations found in the present study were below the detection limit, aluminum, lead and iron concentrations were sometimes higher than permitted by Brazilian legislation for the estuarine class of water (CONAMA, 2005).

The mean $( \pm \mathrm{SD})$ aluminum concentration in the Suape Bay seawater in the study period was $2716 \pm 3770 \mu \mathrm{g}$ total $\mathrm{Al} \mathrm{L}^{-1}$ and can be considered very high when compared to the Brazilian guidelines for class 1 brackish water $\left(100 \mu \mathrm{g} \mathrm{L}^{-1}\right)$ (CONAMA, 2005). Golding et al. (2015) proposed a new

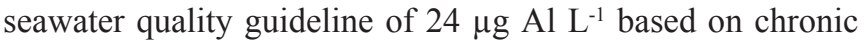

$10 \%$ inhibition or effect concentrations (IC10 or EC10) and NOECs from 11 species (two values from the literature values and nine species tested, including temperate and tropical species) representing six taxonomic groups. It is important to note that no crustacean species were used in this determination. The study cited also found that the echinoderm development test is the least sensitive to aluminum, which may explain the lack of a correlation between pluteus development and $\mathrm{Al}$ concentrations.

The mean $( \pm \mathrm{SD})$ iron concentration in the Suape Bay seawater in the study period was $929.5 \pm 1096 \mu \mathrm{g}$ total $\mathrm{Fe} / \mathrm{L}$ and can also be considered very high when compared to the Brazilian guidelines for class 1 brackish water $\left(300 \mu \mathrm{g} \mathrm{L}^{-1}\right)$ (CONAMA, 2005). Kobayashi \& Okamura (2005) found 210

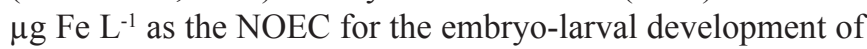
the sea urchin Anthocidaris crassispina. These data suggest that some toxic effect may be related to both high aluminum and iron concentrations in Suape Bay seawater. Both high iron and aluminum concentrations in seawater could be related to the frequent dredging activities in the Suape Harbor. These metals were the most abundant in surface sediments in the area and are probably from natural sources (Marques et al., 2011). It was also found that the copepod development endpoint was also more sensitive to these two metals than the sea urchin endpoint.

Lead occurs naturally from the decomposition of parent rocks and may accumulate from anthropogenic sources, including traffic exhaust as well as industrial and domestic effluents (Lin et al., 2013). A previous study did not detect significant amounts of lead in sediments between 2005 and 2006 in the Suape area (Marques et al., 2011), suggesting anthropogenic sources of $\mathrm{Pb}$ in seawater in 2009. The mean ( \pm SD) lead concentration in seawater was $70.2 \pm 69 \mu \mathrm{g}$ total $\mathrm{Pb} \mathrm{L} \mathrm{L}^{-1}$ and can be considered very high when compared to Brazilian guidelines for class 1 brackish water $\left(10 \mu \mathrm{g} \mathrm{L}^{-1}\right)$ (CONAMA, 2005). Fernandez \& Beiras (2001) determined that the EC50 and lowest effect concentration (LOEC) of $\mathrm{Pb}$ were 509 and $250 \mu \mathrm{g} \mathrm{L}^{-1}$, respectively, using the sea urchin Paracentrotus lividus embryo-larval bioassay. Using bivalve larval development, Beiras \& Albentosa (2004) proposed a LOEC of $\mathrm{Pb}$ from 50 to $156 \mu \mathrm{g} \mathrm{Pb} \mathrm{L}^{-1}$. Kobayashi \& Okamura (2005) found the NOEC of the embryo-larval development of the sea urchin Anthocidaris crassispina to be $34 \mu \mathrm{g} \mathrm{Pb} \mathrm{L} \mathrm{Pb}^{-1}$. Gopalakrishnan et al. (2008) reported the EC50 of larval settlement of the polychaete Hydoides elegans to be $100 \mu \mathrm{g}$ $\mathrm{Pb} \mathrm{L} \mathrm{L}^{-1}$. All these data and the tendency toward an inverse correlation between $\mathrm{Pb}$ levels and the sea urchin and copepod endpoints suggest that the toxic effect of seawater in the Suape bay could be also related to lead.

\section{CONCLUSIONS}

The effect of the seawater in the Suape estuarine complex on delaying naupliar development in $T$. biminiensis was very similar to that found in tests involving embryo-larval development of the sea urchin Lytechinus variegatus. Due 
to the scarcity of individuals of $L$. variegatus in northeastern Brazil and simple culture methods, T. biminiensis nauplii constitute a viable alternative for evaluating seawater toxicity. The aluminum, iron and lead concentrations in surface waters were sometimes higher than Brazilian guidelines for estuarine water, probably due to dredging activities and anthropogenic contamination. These metals could be at least partially responsible for the toxic effects found at different stations and in different months in the Suape estuarine system.

\section{ACKNOWLEDGMENTS}

This study was supported by FINEP/CNPq/Petrobrás in the scope of the RELINE/RECUPETRO project and by the Atlântico Sul Shipyard. The second author received a FACEPE grant for the development of her master's thesis. The authors are grateful to the Department of Zoology of the Federal University of Rio de Janeiro, especially Dr. Ana Bonecker, for enabling the sea urchin test. Acknowledgments to Cristiane Araújo and Arivânia Carmo for help during experiments and Dr. Denis Abessa for contributions to the manuscript.

\section{REFERENCES}

ABNT (Associação Brasileira De Normas Técnicas) 2006. NBR 15350. Ecotoxicologia aquática - Toxicidade crônica de curta duração - Método de ensaio com ouriço-do-mar (Echinodermata: Echinoidea).

ARAUUJO, C.F.C. \& SOUZA-SANTOS L.P. 2013. Use of the microalgae Thalassiosira weissflogii to assess water toxicity in the Suape industrial-port complex of Pernambuco, Brazil. Ecotoxicol. Environ. Saf., 89: 212-221. http://dx.doi.org/1016/j. ecoenv.2012.11.032

ARAÚJO-CASTRO, C. M. V. 2008. O copépodo marinho bentônico Tisbe biminiensis como organismo-teste em avaliações toxicológicas de sedimentos estuarinos. Ph-D Thesis, Universidade Federal de Pernambuco, Recife, $90 \mathrm{p}$.

ARAÚJO-CASTRO C.M.V, SOUZA-SANTOS L.P. \& COSTA M.F. 2006. Efeitos letais e subletais do dicromato de potássio no copépodo bentônico Tisbe biminiensis. In: RELINE - Resíduos Líquidos do Nordeste - Gestão e tratamento de resíduos líquidos gerados na cadeia produtiva do petróleo- $1^{\text {a }}$ Coletânea de trabalhos técnicos. Recife: Ed. Universitária da UFPE. 47-60.

ARAÚJO-CASTRO, C.M.V., SOUZA-SANTOS, L.P., TORREIRO, A.G.A.G. \& GARCIA, K.S. 2009. Sensitivity of the marine benthic copepod Tisbe biminiensis (Copepoda: Harpacticoida) to potassium dichromate and sediment particle size. Braz. J. Oceanogr. 57: 33-41. http://dx.doi.org/10.1590/S167987592009000100004

ASTM (American Society for Testing and Materials) 2004. ASTM (E2317-04). Standard Guide for Conducting Renewal Microplate-Based Life-Cycle Toxicity Tests with a Marine Meiobenthic Copepod.

BECHMANN, R.K. 1999. Effect of the endocrine disrupter nonylphenol on the marine copepod Tisbe battagliai. Sci. Total Environ. 233: 33-46. http://dx.doi.org/10.1016/S00489697(99)00177-1

BEIRAS, R. \& ALBENTOSA, M. 2004. Inhibition of embryo development of the commercial bivalves Ruditapes decussatus and Mytilus galloprovincialis by trace metals; implications for the implementation of seawater quality criteria. Aquaculture 230: 205-213. http://dx.doi.org/10.1016/S0044-8486(03)00432-0

BEZERRA JÚNIOR, J.L., DIAZ, X.F.G. \& NEUMANNLEITAO, S . 2011. Diversidade de Larvas de Peixes das Áreas Internas e Externas do Porto de Suape (Pernambuco - Brazil). Tropical Oceanogr. 39: 1-13. http://dx.doi.org/10.5914//16793013.2011.0048

BRAGA, R. A. P.; UCHOA, T. M. M. \& DUARTE, M. T.M.B. 1989. Impactos ambientais sobre o manguezal de Suape PE. Acta Bot. Bras. 3, suppl.1: 09-27. http://dx.doi.org/10.1590/ S0102-33061989000300003

CESAR, A., MARPIN, A., MARIN-GUIRAO, L. \& VITA, R., 2004. Amphipod and sea urchin tests to assess the toxicity of Mediterranean sediments: the case of Portmán Bay. Scient. Mar. 68 (suppl.1): 205-213. http://dx.doi.org/10.3989/ scimar.2004.68s 1205

CONAMA 2005. Resolução n 357, de 17 de março de 2005. Brazil, Diário Oficial da União 53: 58-63.

CHANDLER, G.T. \& GREEN, A.S., 2001. Developmental stagespecific life- cycle bioassay for assessment of sedimentassociated toxicant effects on benthic copepod production. Environ. Toxicol. Chem. 20: 171-178. http://dx.doi.org/ 10.1897/1551-5028(2001)020<0171:DSSLCB >2.0.CO;2

CHANDLER, G.T., CARY, T., VOLZ, D., WALSE, S., FERRY, J. \& KLOSTERHAUS, S., 2004. Fipronil effects on estuarine copepod (Amphiascus tenuiremis) development, fertility, and reproduction: a rapid life-cycle assay in 96-well microplate format. Environ. Toxicol. Chem. 23: 117-124. http://dx.doi. org/10.1897/03-124

COSTA, B. V. M., YOGUI, G. \& SOUZA-SANTOS, L. P. 2014. Acute toxicity of tributyltin on the marine copepod Tisbe biminiensis. Braz. J. Oceanogr. 62(1):65-69. http://dx.doi. org/10.1590/s1679-87592014075706201

DAHL, U., GOROKHOVA, E. \& BREITHOLTZ, M. 2006. Application of growth-related sublethal endpoints in ecotoxicological assessments using a harpacticoid copepod. Aquat. Toxicol. 77 : 433-438. http://dx.doi.org/10.1016/j. aquatox.2006.01.014

DIZ, F. R, ARAÚJO, C.V.M., MORENO-GARRIDO, I., HAMPEL, M. \& BLASCO, J., 2009. Short-term toxicity tests on the harpacticoid copepod Tisbe battagliai: Lethal and reproductive endpoints. Ecotoxicol. Environ. Saf. 72: 1881-1886. http:// dx.doi.org/10.1016/j.ecoenv.2009.03.004

DRILlET, G., FROUËL S., SICHLAU, M H., JEPSEN, P.M, HØJGAARD, J.K., JOARDER A. K. \& HANSEN B.W. 2011. Status and recommendations on marine copepod cultivation for use as live feed. Aquaculture 315: 155-166. http://dx.doi. org/10.1016/j.aquaculture.2011.02.027

ENVIRONMENT CANADA 1992. Biological test method: fertilization assay using echinoids (Sea Urchins and Sand Dollars). Report EPS 1/ RM/27.

EPA 1992. Method 3005a Acid digestion of waters for total recoverable or dissolved metals for analysis by FLAA or ICP spectroscopy. <http://www.epa.gov/solidwaste/hazard/ testmethods/sw846/pdfs/3005a.pdf $>$ acessed in 10 de abril de 2015.

EPA 2007. Method 6010c Inductively coupled plasma-atomic emission spectrometry < http://www.epa.gov/solidwaste/hazard/ testmethods/sw846/pdfs/6010c.pdf >

FERNÁNDEZ, N. \& BEIRAS, R. 2001. Combined toxicity of dissolved mercury with copper, lead and cadmium on embryogenesis and early larval growth of the Paracentrotus lividus sea-urchin. Ecotoxicology 10: 263-271. http://dx.doi. org/10.1023/A:1016703116830 
FLEEGER, J.W. \& CARMAN, K.R. 2011. Experimental and genetic studies of meiofauna assess environmental quality and reveal mechanisms of toxicity. Vie et Milieu 61:1-26.

FORGET J., PAVILLON J., MENASRIA M. \& BOCQUENE G. 1998. Mortality and LC50 values for several stages of the marine copepod Tigriopus brevicornis (Muller) exposed to the metals arsenic and cadmium and the pesticides atrazine, carbofuran, dichlorvos, and malathion. Ecotoxicol. Environ. Saf. 40: 239244. http://dx.doi.org/10.1006/eesa.1998.1686

FORGET-LERAY, J., LANDRIAU, I., MINIER, C. \& LEBOULENGER, F. 2005. Impact of endocrine toxicants on survival, development, and reproduction of the estuarine copepod Eurytemora affinis (Poppe). Ecotoxicol. Environ. Saf. 60, 288-294. http://dx.doi.org/10.1016/j.ecoenv.2004.06.008

GOLDING, L. A., ANGEL, B.M., BATLEY, G.E., APTE, S.C., KRASSOI, R. \& DOYLE, C.J. 2015. Derivation of a water quality guideline for aluminium in marine waters. Environ. Toxicol. Chem. 34: 141-151. http://dx.doi.org/10.1002/etc.2771

GOPALAKRISHNAN, S., THILAGAM, H., RAJA, P.V. 2008. Comparison of heavy metal toxicity in life stages (spermiotoxicity, egg toxicity, embryotoxicity and larval toxicity) of Hydroides elegans. Chemosphere 71: 515-528. http://dx.doi.org/10.1016/j. chemosphere.2007.09.062

HUANG, Y., ZHU, L. \& LIU, G. 2006. The Effects of bis (tributyltin) oxide on the development, reproduction and sex ratio of calanoid copepod Pseudodiaptomus marinus. Estuar Coast. Shelf Sci., 69:147-152. http://dx.doi.org/10.1016/j.ecss.2006.04.010

IHARA, P. M., PINHO, G. L. L. \& FILLMANN, G. 2010. Avaliação do copépodo Acartia tonsa (Dana, 1849) como organismo-teste para ensaios de toxicidade crônica. J. Bra. Soc. Toxicol. 5: 27-32. http://dx.doi.org/10.5132/jbse.2010.01.005

ISO (International Organization for Standardization) 1999. Standard 14669 - Water quality - Determination of acute lethal toxicity to marine copepods (Copepoda, Crustacea).

KOBAYASHI, N. 1974. Bioassay data for marine pollution using sea urchin eggs, 1972 and 1973. Publi Setorial Mar. Biol. Lab. 21: 411-432.

KOBAYASHI, N. \& OKAMURA, H. 2005. Effects of heavy metals on sea urchin embryo development. Part 2. Interactive toxic effects of heavy metals in synthetic mine effluents. Chemosphere 61: 1198-1203. http://dx.doi.org 10.1016/j. chemosphere.2005.02.071

KOENING, M. L.; ESKINAZI-LEÇA, E.; NEUMANN-LEITÃO, S. \& MACÊDO, S. J. 2002. Impactos da construção do porto de Suape sobre a comunidade fitoplanctônica no estuário do rio Ipojuca (Pernambuco-Brasil). Acta Bot. Bras. 16: 407-420. http://dx.doi.org/10.1590/S0102-33062002000400004.

KUSK, K.O. \& WOLLENBERGER, L. 2007. Towards an internationally harmonized test method for reproductive and developmental effects of endocrine disrupters in marine copepods. Ecotoxicology 16: 183-195. http://dx.doi.org/10.1007/s10646006-0112-2

LAVORANTE, B.O., OLIVEIRA, D.D. COSTA, B.V.M. \& SOUZA-SANTOS, L.P. 2013. A new protocol for ecotoxicological assessment of seawater using nauplii of Tisbe biminiensis (Copepoda:Harpacticoida). Ecotoxicol. Environ. Saf., 95: 52-59. http://dx.doi.org/10.1016/j.ecoenv.2013.05.010

LEE, K., RAISUDDIN, D., HWANG, D., PARK, H. G., DAHMS, H. \& AHN, I. 2008. Two-generation toxicity study on the copepod model species Tigriopus japonicus. Chemosphere 72: 13591365. http://dx.doi.org/10.1016/j.chemosphere.2008.04.023

LEMOS, R.T.O., CARVALHO, P.S.M. \& ZANARDI-LAMARDO, E. 2014. Petroleum hydrocarbons in water from a Brazilian tropical estuary facing industrial and port development. Mar. Pollut. Bull. 82:183-188. http://dx.doi.org/10.1016/j. marpolbul.2014.03.010

LIN, Y.C., CHANG-CHIEN, G.P., CHIANG, P.C., CHEN, W.H. \& LIN, Y.C. 2013. Multivariate analysis of heavy metal contaminations in seawater and sediments from a heavily industrialized harbor in Southern Taiwan. Mar. Pollut. Bull. 76: 266-275. http://dx.doi.org/10.1016/j.marpolbul.2013.08.027

PAIVA, A.C.G. \& ARAÚJO, M.E. 2010. Environmental characterization and spatial distribution of fish fauna in estuaries in the State of Pernambuco, Brazil. Tropical Oceanog. 38:1-46. http://dx.doi.org/10.5914/1679-3013.2010.0038

PINTO, C.S.C., SOUZA-SANTOS, L.P. \& SANTOS, P.J.P., 2001. Development and population dynamics of Tisbe biminiensis (COPEPODA- HARPACTICOIDA) reared on different diets. Aquaculture 198, 253-267. http://dx.doi.org/10.1016/S00448486(00)00582-2

MARQUES, J.S.J.,RANGEL, T. P., BRITO, F. P., ALMDEIA, M. G., SALOMÃO, M. S.M. B., GOBO, A. A. R., SOUZASANTOS, L. P., ARAÚJO-CASTRO, C. M. V., COSTA, M.F. \& REZENDE, C.E. 2011. Geoquímica de metais em sedimentos da zona estuarina do complexo industrial Porto de Suape, PEBrasil. J. Integr. Coastal Zone Manage. 11:379-387. http:// dx.doi.org/10.5894/rgci183

MMA - Ministério do Meio Ambiente, 2014. Portaria no 445, de 17 de dezembro de 2014. Diário Oficial da União. 245: 126-130.

RIBEIRO, A. C.B. \& SOUZASANTOS, L . 2011. Mass culture and offspring production of marine harpacticoid copepod Tisbe biminiensis. Aquaculture 321: 280-288. http://dx.doi. org/10.1016/j.aquaculture.2011.09.016

RESGALLA, JR.C. \& LAITANO, K.S. 2002. Sensibilidade dos organismos marinhos utilizados em testes de toxicidade no Brasil. Notas Téc. Facimar 6:.153-163. http://dx.doi.org/10.14210/ bjast.v6n1.p153-163

SIEGEL, S. 1975. Estatística não paramétrica para as ciências do comportamento. Ed. McGraw-Hill, São Paulo, Brazil.

SILVA, A.P., LEITÃO, S. N., GUSMÃO, L.M.O., SCHWAMBORN, R. \& SILVA, T.A.E. 2004. Mesozooplankton of an impacted bay in Northeastern Brazil. Braz. Arch. Biol. Tech. 47: 485-493. http://dx.doi.org/10.1590/S1516-89132004000300020

SOUZA-SANTOS, L. P.; PASTOR, J.M.O ; FERREIRA, N. G.; COSTA, W. M.; CASTRO, C. M. V. A. \& SANTOS, P. J. P. 2006. Developing the harpacticoid copepod Tisbe biminiensis culture: testing for salinity tolerance, ration levels, presence of sediment and density dependent analyses. Aquacult. Res. 37: 1516-1523. http://dx.doi.org/10.1111/j.1365-2109.2006.01586.x

SOUZA-SANTOS, L.P. \& ARAÚJO, R.J. 2013. Water toxicity assessment in the Suape estuarine complex (PE-Brazil). Ecotoxicol. Environ. Contam. 8: 59-65. http://dx.doi. org/10.5132/eec.2013.01.009

TEMPLETON, R. C., FERGUSON, P. L, WASHBURN, K. M., SCRIVENS, W. A. \& CHANDLER, G. T. 2006. Life-cycle effects of single-walled carbon nanotubes (SWNTs) on an estuarine meiobenthic copepod. Environ. Sci. Technol. 40: 7387-7393. http://dx.doi.org/10.1021/es060407p

USEPA (U.S. Environmental Protection Agency) 1995. Short-term methods for estimating the sublethal toxicity of effluents and receiving waters to west coast marine and estuarine organisms. First edition (EPA/600/R-95-136).

WILLIAMS, T.D., 1992. Survival and development of copepod larvae Tisbe battagliai in surface microlayer water and sediment elutriates from the German Bight. Mar. Ecol. Prog. Ser. 91: 221228. http://dx.doi.org/10.3354/meps091221

ZAGATTO, P.A. \& BERTOLETTI, E. 2006. Ecotoxicologia Aquática - Princípios e Aplicações. São Paulo, SP, Brasil. Editora Rima. 